\title{
JOURNAL.RU
}

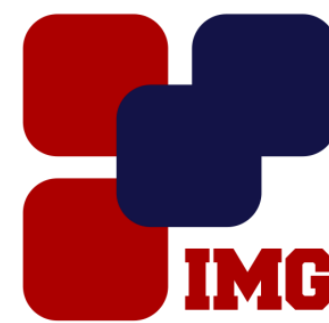
IVANOY Management GROUP

Фомина К.А., Чиркова Н.В., Вечеркина Ж.В., Полушкина Н.А., Плутахина А.А. Воронежский государственный медиџинский университет имени Н. Н. Бурденко Воронеж, Россия

doi: $10.18411 / 1 \mathrm{j}-30-06-2017-08$

idsp 000001:1j-30-06-2017-08

\section{«Изучение современные методик для поддержания «чистоты» съемных ортопедических конструкций из термопласта»}

В настоящее время возрастает число лиц пожилого и старческого возраста с дефектами зубных рядов и полным отсутствием зубов, в тоже время увеличивается количество больных с этой патологией в более младших возрастных группах $[1,12]$. Съемные ортопедические конструкции из термопластических полимеров нашли свое широкое применение благодаря наличию комплекса положительных физико - механических, технологических и биологических свойств. Спектр термопластических полимеров, дающих возможность изготовить легкие, прочные безметалловые съемные протезы очень широк. На сегодняшний день наиболее распространенными термопластическими полимерами являются полиамиды - нейлоны. Нейлон - это первый синтетический полимер, физические свойства которого превосходят свойства некоторых металлов. Он имеет невероятное сочетание свойств: высокую прочность, среднюю жесткость, устойчивость к высоким температурам и химикатам. Нейлоны - это биосовместимые термопластические полимеры с высокими физическими и эстетическими свойствами. Съемные протезы, изготовленные из нейлона, обладают достаточной высокой гибкостью, противостоят разломам. Пациенты, которые пользовались как обычными, так и нейлоновыми протезами отмечают, что протезы из нейлона более комфортны и натуральны во рту и незаметны для окружающих, благодаря превосходной ретенции и эстетики. Анализ данных свидетельствует о том, что к настоящему времени предложен обширный спектр базисных материалов, к которым появились повышенные требования к качеству, комфорту и высокой эстетике. 
Однако они должны иметь и высокие гигиенические характеристики, так как именно эти показатели влияют на эксплуатационные свойства[4,7].

Повышение качества ортопедического лечения съемными конструкциями зубных протезов зависит от продолжительности их использования. Значимым фактором, приводящим к замене зубных протезов и возникновению риска стоматологических заболеваний у пациентов со съемными ортопедическими конструкциями, является их неудовлетворительное гигиеническое состояние[2,5]. В результате нарушения гигиены полости рта возникает неприятный запах изо рта - галитоз, который мешает свободному общению, уменьшает коммуникативные возможности и, как следствие, ухудшает качество жизни[10]. Причиной неприятного запаха изо рта могут быть парадонтопатогенные микроорганизмы, ксеростомия, которая приводит к возрастанию количества микроорганизмов и появлению микробного дисбаланса в полости рта, усилению ферментативных процессов, что способствует повышению интоксикации организма[5].

Целью данного исследования является изучение таких важных проблем в современной практической ортопедической стоматологии - оценка дезинфицирующих средств, а также способов, применяемых в практике дезинфекции основных и вспомогательных материалов.

На поверхности базисов съемных зубных протезов существуют микроскопические поры, и ортопедические конструкции из термопластов не являются исключением, что связано с технологическими трудностями окончательного этапа обработки термопластических полимеров[11]. На одном протезе, по данным различных авторов, содержится от $1 \times 105$ до $2 \times 105$ микроорганизмов, что соответствует числу микробов на оттиске. Часть этих микроорганизмов высоко резистентны к воздействию факторов внешней среды[3]. При обсеменении съемных протезов колониями микроорганизмов возникает необходимость обрабатывать их антисептиками, дезодорантами и специальными средствами. Механическая очистка, даже с помощью ультразвуковых приборов, может лишь отчасти удалить микроорганизмы (бактерии и грибы) с поверхности протезов. Необходимо дополнительно обработать поверхность химическими и дезинфицирующими средствами. Очищение с помощью химических и дезинфицирующих средств - важный компонент эффективного ухода за искусственными зубами[4].Для определения степени чистоты зубных протезов применяют индексную оценку гигиены с использованием индикаторов зубного налета, позволяющие не только 
объективизировать субъективные данные скопления зубного налета, но и проследить тенденции в его росте [8].

На отечественном стоматологическом рынке представлены специальные средства для очистки и дезинфекции съемных зубных протезов. Существуют препараты и способы, предназначенные только для очищения протезов, или только для дезинфекции, а также сочетающие в себе функции очищения и дезинфекции. Иногда встречаются случаи возникновения аллергической реакции на готовые чистящие средства для протезов[6].

Для оценки эффективности действия дезинфицирующих растворов чаще всего используется микробиологический анализ смывов с обрабатываемой поверхности. Микробиологическое исследование играет важную роль в диагностике, профилактике и лечении инфекционных и гнойно-воспалительных заболеваний. Основная цель бактериологического исследования - установить факт наличия или отсутствия возбудителя на поверхности того или иного объекта, его качественная характеристика и идентификация[3]. Данный метод заключается в следующем: исследуемый материал собирают тампоном непосредственно с поверхности, подвергшейся микробному загрязнению (оттиски, восковые композиции и протезы после врачебных манипуляций). Полученный патологический материал для микробиологического исследования должен быть доставлен в лабораторию, где его микроскопируют и засевают на плотные питательные среды общего назначения (кровяной, шоколадный, сывороточный агар), а также селективно-ингибирующие среды. Выбор набора питательных сред зависит от вида исследуемого материала и цели исследования. Непременным условием является получение изолированных колоний, используемых для получения чистых культур, их дифференциации и дальнейшей идентификации. Параллельно испытуемый материал засевают в жидкие или полужидкие среды обогащения (сахарный бульон, сывороточный бульон, тиогликолевая среда), что особенно важно при содержании небольшого количества микроорганизмов в биоматериале. Посевы инкубируются в термостате в течение 3-5 дней с ежедневным высевом на плотные питательные среды [4].

Согласно проведенному детальному анализу литературного обзора по изучению «чистоты» ортопедических конструкций из термопластических материалов в процессе эксплуатации, микробиологическое исследование -это основа в изучении эффективности дезинфицирующих средств и методов дезинфекции в современной ортопедической стоматологии 
В связи с появлением на рынке новых микробиологических анализаторов, вероятно, появятся и новые тест-системы для идентификации микроорганизмов, пригодные не только для автоматизированного считывания с помощью анализатора, но и для визуального учета результатов с последующей идентификацией с помощью профилей или компьютерных программ, требующие последующего изучения для выполнения главной задачи ортопедической стоматологии - повышения уровня стоматологического здоровья пациентов, пользующимися съемными зубными протезами из современных конструкционных материалов.

\section{Литература}

1. Анализ воспалительно-дистрофических процессов в тканях полости рта у больных сахарным диабетом 2 типа / Н.А Полушкина, А.Н. Морозов, Т.В. Чубаров Ж.В. Вечеркина / Системный анализ и управление в биомедицинских системах.- 2016.T.15, №1.-C.18-21

2. Анализ факторов, влияющих на период адаптации пациентов к съемным пластиночным протезам / Ж.В. Вечеркина, Т.А. Попова, А. Заидо, К.А. Фомина. / Системный анализ и управление в биомедицинских системах.- 2016.- Т.15, №1.-С.8083.

3. Голубева Л.А. Экспериментально - клиническое обоснование эффективности дезинфекции съемных пластиночных протезов раствором, содержащим ионы серебра: дис. ... канд. мед. наук. Воронеж, 2013. 140 с.

4. Каливраджиян, Э.С. Руководство по стоматологическому материаловедению / Э.С. Каливраджиян, Е.А. Брагин. - М.: Медицинское информационное агентство, 2013. $304 \mathrm{c}$.

5. Коммунальная стоматология: учебно - методическое пособие / А.Н. Морозов [и др.].Воронеж, 2016.-125 с.

6. Медико-социальная значимость проблемы дезинфицирующей обработки съемных протезов у лиц пожилого возраста / К.А. Фомина, Н.В. Чиркова, Ж.В. Вечеркина, А.Н. Морозов, Т.А. Попова / Системный анализ и управление в биомедицинских системах.2016.- Т.15, № 4.-С.692-695.

7. Опыт применения биологически активных пленок в клинической стоматологии / Примачева Н.В., Морозов А.Н., Попова Т.А., Бобешко М.Н., Пшеничников И.А., Корецкая И.В., Шелковникова С.Г. / Здоровье семьи XXI век.- 2015.- Т. 1.- С.309-312.

8. Пропедевтика хирургической стоматологии (учебное пособие) / Морозов А.Н., Чиркова Н.В., Корецкая И.В., Пшеничников И.А., Борисова Э.Г., Шелковникова С.Г., Попова Т.А., Примачева Н.В., Андреева Е.А. // Международный журнал прикладных и фундаментальных исследований. - 2014. л- № 3. - С. 158-159.

9. Профилактическая стоматология: Учебник / Э. М. Кузьмина, О.О. Янушевич.- М.: Практическая медицина, 2016.- 544 с. 
10. Роль антисептической лечебно-профилактической жидкости во время стоматологического приема / Заидо Абдулкадер, А.Н. Морозов, Ж.В. Вечеркина, Н.В. Чиркова// Системный анализ и управление в биомедицинских системах. - 2014. - Т.13, №4. - C.847-849.

11. Чиркова Н.В. Токсичность полировочной пасты «ПОЛИРПРО» для окончательной обработки термопластических полимеров стоматологического назначения / Н.В. Чиркова, Ж.В. Вечеркина, И.В. Корецкая, Е.В. Рубцова // Научно-медицинский вестник Центрального Черноземья, 2015. - № 62. - С. 82-86.

12. The use of led radiation in prevention of dental diseases / МоисееваН.С., ИпполитовЮ.А.,КунинД.А., МорозовА.Н., ЧирковаН.В. / The EPMА Journal.- 2016.- Т. 7, № S 1.- C.24. 